Diskussionspapier Nr. 9

\author{
Heike Link
}

An econometric analysis of

motorway renewal costs in Germany

Institut für Verkehrswissenschaft

D-48143 Münster, Am Stadtgraben 9

Juli 2004 


\title{
An econometric analysis of motorway renewal costs in Germany*
}

\author{
Heike Link ${ }^{*}$
}

\section{Contents}

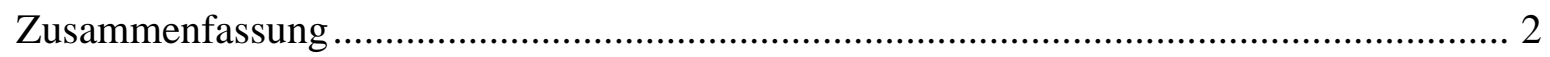



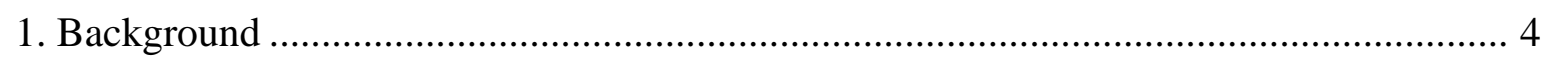

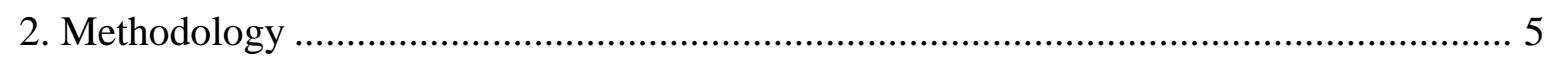



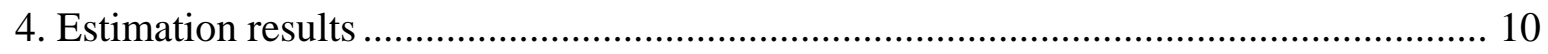

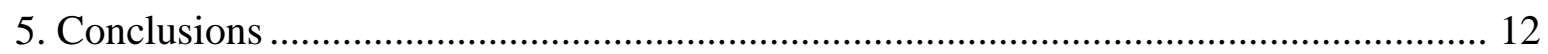

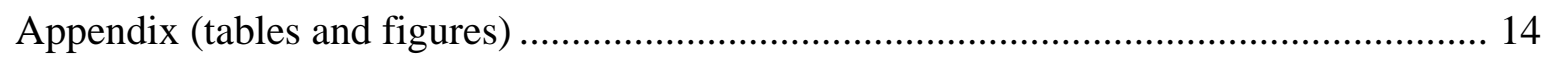

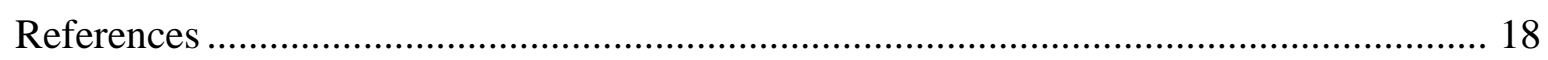

* This research was part of the EU funded project UNITE (UNIfication of accounts and marginal costs for Transport Efficiency) under the $5^{\text {th }}$ Framework Programme on RTD. The full project reports can be found under www.its.leeds.ac.uk/projects/unite. Thanks to Catharina Sikow, the project officer of the UNITE projects for a fruitful cooperation. I am also grateful to Chris Nash, ITS Leeds, and Thomas Fridtjof, VTI Borlänge, for useful discussions and to the referees for their comments.

* German Institute for Economic Research (DIW Berlin), Königin-Luise-Str. 5, 14195 Berlin, Germany Tel.: +49-30-89789312; fax: +49-30-89789113, E-mail: hlink@diw.de 


\section{Zusammenfassung}

Die in diesem Diskussionspapier vorgestellte Arbeit analysiert den Zusammenhang zwischen den Erneuerungskosten auf Autobahnen einerseits und der Verkehrsbelastung sowie den Faktorinputpreisen für Arbeit, Material und Kapital andererseits. Die Untersuchung basiert auf Querschnittsdaten für das westdeutsche Autobahnnetz für den Zeitraum von 1980 bis 1999. Unter Verwendung eines Translog-Ansatzes werden zwei Modelle für Kostenfunktionen der Straßenerneuerung geschätzt. Modell I beschreibt den ökonomischen Prozess der Straßenerneuerung als Zusammenhang zwischen den Erneuerungskosten, der erneuerten Fläche und den Faktorpreisen für Arbeit, Material und Kapital. Ein zweites Modell (Modell II) orientiert sich stärker am Prozess der Straßenschädigung und Kostenentstehung und bildet den Zusammenhang zwischen Erneuerungskosten, Verkehrsbelastung und wiederum den Faktorpreisen für Arbeit, Material und Kapital ab.

Die Schätzergebnisse für Modell I zeigen, dass im Prozess der Straßenerneuerung Material und Arbeit komplementäre Faktorinputs darstellen, während Kapital und Arbeit sowie Kapital und Material Substitute sind. Darüber hinaus ergeben sich aus den Modellergebnissen Economies of Scale bei der Straßenerneuerung, die darauf hindeuten, dass bei der Vergabe von Straßenerneuerungsarbeiten größere Lose sinnvoll erscheinen, vorausgesetzt, dass dem nicht Restriktionen hinsichtlich unerwünschter Verkehrseinschränkungen entgegenstehen.

Modell II ermöglicht die Ableitung von Grenzkosten der Infrastrukturbenutzung durch den Güterverkehr, die für die Bestimmung optimaler Preise nach dem Prinzip der sozialen Grenzkosten bedeutsam sind. Diese Information ist unmittelbar relevant für die Preispolitik im Verkehr. Die sich aus Modell II ergebende Kostenelastizität (das Verhältnis von Grenzkosten und Vollkosten) ist eine degressiv steigende Funktion der Verkehrsbelastung und liegt zwischen 0,05 und 1,17. Aus der Multiplikation mit den Durchschnittskosten ergeben sich hieraus Grenzkosten zwischen 0,08 bis 1,87 € pro Fahrzeugkilometer. 


\begin{abstract}
This paper analyses the cost behaviour of motorway renewal costs with the aim to derive an estimate of marginal infrastructure costs per vehicle-km of trucks as part of optimal road user charges. The analysis is based on cross-sectional data of motorway renewal costs and traffic volume per motorway section in Germany during the period 1980-1999. The translog model estimated in this paper includes the factor input prices for labour, material and capital, the average annual daily traffic volume of trucks and passenger cars with the respective secondorder terms, and a set of dummy variables for regions (the German länder) as well as for the type of material used for renewal as the most important explanatory variables. In contrast to this, we could not find any significant influence of the age of motorway sections, the past renewal expenditures and the climate conditions measured as days with temperature fluctuations around zero. The cost elasticity, i.e. the relationship between marginal and average costs found in this analysis ranges from 0.05 up to 1.17 with a digressive increase of marginal costs.
\end{abstract}

Keywords: Cost functions, motorway renewal costs, marginal costs, infrastructure charging, road transport

JEL codes:

R48, L92, C31 


\section{Background}

One component of optimal prices for road use is the marginal cost of road maintenance and renewal. While extensive studies on optimal congestion and environmental charges as well as the respective cost estimates are available much less attention has been paid to the estimation of marginal road infrastructure costs. Econometric studies on cost functions for road infrastructure are rare ${ }^{1}$. Newbery 1988a, Newbery 1988b and Newbery 1989 provide theoretical attempts to the problem but lack the empirical evidence. Other studies such as Talvitie/Sikow 1992 analyse rather the productive efficiency of highway construction work by means of frontier cost functions. Cost allocation studies in Germany, Switzerland, Sweden and other countries conducted within the context of public road accounts usually assume a linear cost curve with marginal costs equal to variable costs and derive the fraction of variable costs based on expert opinions and judgements (see Link et al. 1999). Alternative approaches are engineering experiments such as the AASHO Road Test (see Highway Research Board 1961) which concluded the so-called fourth power rule reflecting the relationship between axle weight and road damages. However, the opportunities to conduct large-scale experiments are rather limited. Small et al. 1989 have introduced an engineering based approach of estimating an elasticity of road deterioration with respect to axle-loads. This approach was also applied in Lindberg 2002 who uses measurements of road conditions from the Swedish Long-Term Pavement Management Programme.

The analysis described in this paper employs a translog cost function approach to the problem. It analyses the renewal costs of German motorways during the period 1980-1999 based on cross-sectional data on motorway renewal expenditures, factor inputs and factor prices and traffic volume in West Germany. The paper is organised as follows: Chapter 2 discusses the methodological approach. Chapter 3 describes the input data used. Chapter 4 presents the estimation results and derives marginal renewal costs. Chapter 5 concludes.

\footnotetext{
${ }^{1}$ This is also true for other modes than road. Exceptions are Johansson/Nilsson 2001 which estimated a translog cost function for rail maintenance costs in Sweden and Finland, and Gaudry/Quinet 2003 which derived a BoxCox cost function for rail maintenance in France.
} 


\section{Methodology}

Over the last 30 years economic literature has suggested a variety of different functional forms to describe producers behaviour. The translog approach, introduced for example in Berndt/Christensen 1973 and Christensen et al. 1975, has remained to be the most frequently used form (for an overview of applications in transport see Oum/Waters 1998). It imposes only few restrictions on the underlying production technology, allows a simple computation of substitution elasticities and contains all relevant properties of neoclassical production theory such as factor substitution, economies of scale and technological change. The Box-Cox model later on suggested by Berndt/Khaled 1979 is an even more general tool which contains the generalised Leontief function and the multiple-output translog function as special cases.

The major methodological difference between the context analysed in this paper and traditional cost functions employed so far in transportation research is the definition of the output variable. Defining the traffic volume of different vehicle types as output variable is not as straightforward as in existing cost function studies for example for the trucking industry or for rail transport (for example Daughety et al. 1985, De Borger 1992, Cantos 2000). While train$\mathrm{km}$, gross-tonne-km or passenger-km in rail transport are produced by the rail company with a combination of factor inputs such as energy, material, labour and capital, the factor inputs used for renewal work of motorways are not those used for producing vehicle-km of passenger cars and goods vehicles. The latter are produced by the factor inputs of haulage companies or individuals. The obvious way to define the output of motorway renewal work is a measurement of renewed road, expressed for example as sqm or cbm. This allows an analysis of factor input substitution, productivity and economies of scale. Since the main interest of this paper is to estimate marginal costs of infrastructure use, the logical consequence would be to incorporate traffic volume with the respective second-order and interaction terms into such a basic economic model. However, initial modelling attempts revealed that the strong effect of the output variable, measured as sqm renewed road, leads to insignificant and implausible parameter estimates for the traffic variables, in particular for goods vehicles. Therefore, two different translog models were adopted to analyse motorway renewal costs.

Model I seeks to analyse the economic process of renewing motorways as such, e.g. explaining the renewal costs $C_{i}$ by the output variable $Y_{i}$ defined as the sqm of motorways renewed at each section i over the analysis period, and a vector of input prices $\mathrm{W}^{\prime}=\left(\mathrm{w}_{\mathrm{e}}, \mathrm{w}_{\mathrm{m}}, \mathrm{w}_{\mathrm{c}}\right)$ for 
labour, material and capital. $\mathrm{D}_{\mathrm{ij}}$ are dummy variables indicating the federal state $\mathrm{j}(\mathrm{j}=1, \ldots, \mathrm{m}$; $m=8)$, and $M_{i k}$ denote dummy variables for the material used for renewals $(k=1, \ldots, K ; K=7$, see table 1). This basic model has the form

$$
\begin{aligned}
\ln \mathrm{C}_{\mathrm{i}} & =\mathrm{c}+\sum_{\mathrm{j}=1}^{\mathrm{m}} \alpha_{\mathrm{j}} \cdot \mathrm{D}_{\mathrm{ij}}+\sum_{\mathrm{k}=1}^{\mathrm{K}} \delta_{\mathrm{k}} \cdot \mathrm{M}_{\mathrm{ik}}+\beta_{\mathrm{y}} \cdot \ln \mathrm{Y}_{\mathrm{i}}+\beta_{\mathrm{l}} \cdot \ln \mathrm{W}_{\mathrm{li}}+\beta_{\mathrm{m}} \cdot \ln \mathrm{W}_{\mathrm{mi}}+\beta_{\mathrm{c}} \cdot \ln \mathrm{W}_{\mathrm{ci}} \\
& +\frac{1}{2} \cdot\left(\beta_{\mathrm{yy}} \cdot \ln \mathrm{Y}_{\mathrm{i}} \cdot \ln \mathrm{Y}_{\mathrm{i}}+\beta_{\mathrm{ll}} \cdot \ln \mathrm{W}_{\mathrm{li}} \cdot \ln \mathrm{W}_{\mathrm{li}}+\beta_{\mathrm{mm}} \cdot \ln \mathrm{W}_{\mathrm{mi}} \cdot \ln \mathrm{W}_{\mathrm{mi}}+\beta_{\mathrm{cc}} \cdot \ln \mathrm{W}_{\mathrm{ci}} \cdot \ln \mathrm{W}_{\mathrm{ci}}\right) \\
& +\beta_{\mathrm{yl}} \cdot \ln \mathrm{Y}_{\mathrm{i}} \cdot \ln \mathrm{W}_{\mathrm{li}}+\beta_{\mathrm{ym}} \cdot \ln \mathrm{Y}_{\mathrm{i}} \cdot \ln \mathrm{W}_{\mathrm{mi}}+\beta_{\mathrm{yc}} \cdot \ln \mathrm{Y}_{\mathrm{i}} \cdot \ln \mathrm{W}_{\mathrm{ci}} \\
& +\beta_{\mathrm{lm}} \cdot \ln \mathrm{W}_{\mathrm{li}} \cdot \ln \mathrm{W}_{\mathrm{mi}}+\beta_{\mathrm{lc}} \cdot \ln \mathrm{W}_{\mathrm{li}} \cdot \ln \mathrm{W}_{\mathrm{ci}}+\beta_{\mathrm{mc}} \cdot \ln \mathrm{W}_{\mathrm{mi}} \cdot \ln \mathrm{W}_{\mathrm{ci}} \cdot
\end{aligned}
$$

The cost-minimising factor demands are obtained by applying Shephard's (1970) lemma

$$
\begin{aligned}
& \mathrm{S}_{\mathrm{l}}=\frac{\partial \ln \mathrm{C}_{\mathrm{i}}}{\partial \ln \mathrm{W}_{\mathrm{li}}}=\beta_{\mathrm{l}}+\beta_{\mathrm{ll}} \cdot \ln \mathrm{W}_{\mathrm{li}}+\beta_{\mathrm{yl}} \cdot \ln \mathrm{Y}_{\mathrm{i}}+\beta_{\mathrm{lm}} \cdot \ln \mathrm{W}_{\mathrm{mi}}+\beta_{\mathrm{lc}} \cdot \ln \mathrm{W}_{\mathrm{ci}} \\
& \mathrm{S}_{\mathrm{c}}=\frac{\partial \ln \mathrm{C}_{\mathrm{i}}}{\partial \ln \mathrm{W}_{\mathrm{ci}}}=\beta_{\mathrm{c}}+\beta_{\mathrm{cc}} \cdot \ln \mathrm{W}_{\mathrm{ci}}+\beta_{\mathrm{yc}} \cdot \ln \mathrm{Y}_{\mathrm{i}}+\beta_{\mathrm{lc}} \cdot \ln \mathrm{W}_{\mathrm{li}}+\beta_{\mathrm{mc}} \cdot \ln \mathrm{W}_{\mathrm{mi}} \\
& \mathrm{S}_{\mathrm{m}}=\frac{\partial \ln \mathrm{C}_{\mathrm{i}}}{\partial \ln \mathrm{W}_{\mathrm{mi}}}=\beta_{\mathrm{m}}+\beta_{\mathrm{mm}} \cdot \ln \mathrm{W}_{\mathrm{mi}}+\beta_{\mathrm{ym}} \cdot \ln \mathrm{Y}_{\mathrm{i}}+\beta_{\mathrm{lm}} \cdot \ln \mathrm{W}_{\mathrm{li}}+\beta_{\mathrm{mc}} \cdot \ln \mathrm{W}_{\mathrm{ci}}
\end{aligned}
$$

The necessary conditions for homogeneity in input prices and for symmetry are

$$
\sum_{\mathrm{i}} \beta_{\mathrm{i}}=1, \quad \sum_{\mathrm{i}} \sum_{\mathrm{j}} \beta_{\mathrm{ij}}=0, \quad \sum_{\mathrm{i}} \beta_{\mathrm{yi}}=0 \text {, and } \beta_{\mathrm{ij}}=\beta_{\mathrm{ji}} \quad \text { respectively, where } \mathrm{i}=\mathrm{l}, \mathrm{m}, \mathrm{c} \text {. }
$$

Due to the fact that the dependent variable was constructed as the sum of renewal expenditures over 20 years (see chapter 3), the model does not allow to analyse possible changes of technologies for renewal measures.

Model II establishes the relationship between renewal costs and the traffic volume $\mathrm{u}_{\mathrm{fi}}$ and $\mathrm{u}_{\mathrm{pi}}$ of goods vehicles and passenger cars respectively, expressed as the annual average daily traffic volume (AADT). $E_{i}$ are the renewal costs before the period of analysis (defined as catego- 
rical variable with the levels $0,1,2,3), l_{i}$ is the number of lanes, $a_{i}$ is the age of motorway sections. The cost behaviour is then described as

$$
\begin{aligned}
& \ln C_{i}=c+\sum_{j=1}^{m} \alpha_{j} \cdot D_{i j}+\sum_{k=1}^{K} \delta_{k} \cdot M_{i k}+\gamma_{1} \cdot E_{i}+\gamma_{2} \cdot \ln l_{i} \\
& +\beta_{\mathrm{l}} \cdot \ln \mathrm{p}_{\mathrm{li}}+\beta_{\mathrm{m}} \cdot \ln \mathrm{p}_{\mathrm{mi}}+\beta_{\mathrm{c}} \cdot \ln \mathrm{p}_{\mathrm{ci}}+\beta_{\mathrm{f}} \cdot \ln \mathrm{u}_{\mathrm{fi}}+\beta_{\mathrm{p}} \cdot \ln \mathrm{u}_{\mathrm{pi}}+\beta_{\mathrm{a}} \cdot \ln \mathrm{a}_{\mathrm{i}} \\
& +\frac{1}{2}\left[\beta_{\mathrm{ll}} \cdot \ln ^{2} \mathrm{p}_{\mathrm{li}}+\beta_{\mathrm{mm}} \cdot \ln ^{2} \mathrm{p}_{\mathrm{mi}}+\beta_{\mathrm{cc}} \cdot \ln ^{2} \mathrm{p}_{\mathrm{ci}}+\beta_{\mathrm{ff}} \cdot \ln ^{2} \mathrm{u}_{\mathrm{fi}}+\beta_{\mathrm{pp}} \cdot \ln ^{2} \mathrm{u}_{\mathrm{pi}}+\beta_{\mathrm{aa}} \cdot \ln ^{2} \mathrm{a}_{\mathrm{i}}\right] \\
& +\beta_{\mathrm{lc}} \cdot \ln \mathrm{p}_{\mathrm{li}} \cdot \ln \mathrm{p}_{\mathrm{ci}}+\beta_{\mathrm{lm}} \cdot \ln \mathrm{p}_{\mathrm{li}} \cdot \ln \mathrm{p}_{\mathrm{mi}}+\beta_{\mathrm{mc}} \cdot \ln \mathrm{p}_{\mathrm{mi}} \cdot \ln \mathrm{p}_{\mathrm{ci}}+\beta_{\mathrm{pf}} \cdot \ln \mathrm{u}_{\mathrm{fi}} \cdot \ln \mathrm{u}_{\mathrm{pi}} \\
& +\beta_{\mathrm{af}} \cdot \ln \mathrm{a}_{\mathrm{i}} \cdot \ln \mathrm{u}_{\mathrm{fi}}+\beta_{\mathrm{ap}} \cdot \ln \mathrm{a}_{\mathrm{i}} \cdot \ln \mathrm{u}_{\mathrm{pi}} \cdot
\end{aligned}
$$

with the input cost share equations

$$
\begin{aligned}
& \mathrm{S}_{\mathrm{l}}=\frac{\partial \ln \mathrm{C}_{\mathrm{i}}}{\partial \ln \mathrm{p}_{\mathrm{li}}}=\beta_{\mathrm{l}}+\beta_{\mathrm{ll}} \cdot \ln \mathrm{p}_{\mathrm{li}}+\beta_{\mathrm{lc}} \cdot \ln \mathrm{p}_{\mathrm{ci}}+\beta_{\mathrm{lm}} \cdot \ln \mathrm{p}_{\mathrm{mi}} \\
& \mathrm{S}_{\mathrm{c}}=\frac{\partial \ln \mathrm{C}_{\mathrm{i}}}{\partial \ln \mathrm{p}_{\mathrm{ci}}}=\beta_{\mathrm{c}}+\beta_{\mathrm{cc}} \cdot \ln \mathrm{p}_{\mathrm{ci}}+\beta_{\mathrm{lc}} \cdot \ln \mathrm{p}_{\mathrm{li}}+\beta_{\mathrm{mc}} \cdot \ln \mathrm{p}_{\mathrm{mi}} \\
& \mathrm{S}_{\mathrm{m}}=\frac{\partial \ln \mathrm{C}_{\mathrm{i}}}{\partial \ln \mathrm{p}_{\mathrm{mi}}}=\beta_{\mathrm{m}}+\beta_{\mathrm{mm}} \cdot \ln \mathrm{p}_{\mathrm{mi}}+\beta_{\mathrm{lm}} \cdot \ln \mathrm{p}_{\mathrm{li}}+\beta_{\mathrm{mc}} \cdot \ln \mathrm{p}_{\mathrm{ci}}
\end{aligned}
$$

As in model I, the usual conditions for input price homogeneity and symmetry are imposed. The two models (1) - (4) and (5) - (8) allow different directions of analysing motorway renewal costs. While model I is a pure economic model allowing to analyse substitution elasticities and economies of scale in the process of renewing motorways, model II enables to analyse the influence which traffic volume and traffic composition have on the level and shape of the cost curve and to derive marginal costs for trucks.

Both types of translog models were estimated jointly with the cost-minimising input cost share functions. The estimation involved standardising each variable other than the factor shares, taking logarithms and dropping the last factor share equation by dividing the standardised costs and the labour and capital price by the standardised price of material. The system of equations which provides a seemingly unrelated regression model (SUR model) was estima- 
ted by means of the constrained ML estimator within the SURE procedure of LIMDEP. This procedure guarantees maximum-likelihood estimates that are invariant with respect to which factor share equation is dropped (Barten 1969).

\section{Description of input data}

The dependent variable, the renewal costs per motorway section, was constructed from two sources. First, the study had access to a data base with a detailed physical, non-monetary description of each renewal measure (length and type of measure, material used, thickness of layers concerned) for 1830 road sections of the German motorway network (see ASTRA 2001). This data, which excludes renewals of bridges and tunnels, is disaggregated for different road layers and covers all measures taken within the last 20 years, in many cases even reaching back to the 50's and before. Second, unit costs at 2000 prices for each type of construction were used to express the physical description of the measures in monetary terms. ${ }^{1}$ Further data treatment was necessary due to the fact that renewal expenditures are to a large extent investments rather than running expenditures, and their spending behaviour over time follows a cyclical pattern. The data base contained therefore only for a small percentage of sections renewal expenditures in single years. In order to obtain a more densely populated regression matrix and to smooth the cyclical pattern, the annual expenditures were summed up for the period from 1980 to 1999. The analysis refers to West German motorways only since extraordinary high maintenance and renewal expenditures spent in East Germany after the German re-unification would bias the results. The renewal data used for the econometric analysis in this paper amount to a fraction of about $70 \%$ of replacement expenditures for West German motorways (see Kunert/Link 1999).

The set of explanatory variables contains for each motorway section the factor input quantities and input prices for labour, material and capital, the annual average daily traffic volume (AADT) of passenger cars and goods vehicles ${ }^{2}$, the number of lanes, the type of material used

\footnotetext{
${ }^{1}$ This working step was carried out by one of the leading engineering consultancies in the field of pavement management systems in Germany (SEP Maerschalk).

2 Disaggregated traffic data for vehicle categories such as light goods vehicles, heavy goods vehicles with trailer, heavy goods vehicles without trailer, busses was only available for three single years (1990, 1993 and 1995) and only for a few federal states in Germany.
} 
for renewal, the age of motorways at the beginning of the analysis period, the renewal expenditures before the analysis period and the climate conditions (table 1).

The factor inputs for labour and material were derived from the input quantities (material used and labour hours spent) used in the monetary valuation of physical renewal measures. Capital input was estimated by using regional data on capital stock for equipment in the construction sector. Input prices were derived from official regional statistics.

The traffic data was derived from automatic vehicle counting stations and refers to about 400 motorway sections. Gaps in the data due to failures of the devices and other reasons were closed as long as the share of necessary estimates was small enough not to bias the regression results. In order to account for the influence of maintenance and renewal practice in the past, two variables were introduced: one reflecting the renewal expenditures before the analysis period (as categorical variable due to problems with zero expenditures when taking logarithms), and another one indicating the age of motorway sections ${ }^{1}$. A set of dummy variables indicating the type of construction used for the renewals was introduced to control for the effect of more expensive types of renewal measures on the dependent variable. ${ }^{2}$ Furthermore, expert opinion suggests that road damages are also caused by climate conditions (see for example Hermansson 2001, Rübensam/Schulze 1995), in particular by fluctuations of temperature around zero. Therefore, a variable "number of days with temperature fluctuations around zero" was constructed by using data from 260 climate stations.

The final data set contained 221 observations, e.g. substantially less cases than the original data (1837 observations) due to problems with missing or zero observations in one of the variables.

Table 2 shows the minimum and maximum values for the variables used and the mean and standard deviation. On average, DM mill. 1.95 ( $€$ mill. 0.997) was spent per motorway section for renewals during the period 1980-1999, (around $€ 50000$ per section and year). With these expenditures around 32000 sqm motorways were renewed. As the AADT figures for 1999

\footnotetext{
${ }^{1}$ Ideally, the analysis should rather consider the number of years having passed since the last renewal. Since the data base does not contain a complete construction and renewal history for all sections it was not possible to construct such a variable. However, the age variable and the past maintenance variable reflect indirectly the influence of construction standards and quality as well as the traffic volume and composition anticipated in the design of motorways at the time of construction, and the renewal practice before the period of analysis.

${ }^{2}$ No cross-sectional data on the construction type at the beginning of the analysis period was available. It was thus not possible to analyse the impact of different construction types on the renewal cycle.
} 
indicate, the West German motorways belong with an AADT of 26632 passenger cars and 5002 trucks to the highly utilised motorway networks in Europe.

\section{Estimation results}

Table 3 shows the estimation results for the translog models given in (1) - (4) and (5) - (8). To start with model I we can observe that almost all coefficients have the expected signs and are significant at 5\% critical level. Exceptions are the interaction terms between labour and capital (not significant and wrong sign), between output and material (wrong sign) and the interaction coefficient $\beta_{\mathrm{yl}}$ (not significant). The input cost shares and the price elasticities of factor demand are positive, e.g. it is guaranteed that the estimated cost function is monotonous increasing and concave regarding the input prices.

Table 4 shows the Allen-Uzawa substitution elasticities between any pair of input factors

$\varepsilon_{\mathrm{ij}}=\frac{\beta_{\mathrm{ij}}+\mathrm{s}_{\mathrm{ij}}}{\mathrm{s}_{\mathrm{i}} \cdot \mathrm{s}_{\mathrm{j}}}$

and the own price elasticities of each factor demand

$\varepsilon_{\mathrm{ii}}=\frac{\beta_{\mathrm{ii}}+\mathrm{s}_{\mathrm{i}}\left(\mathrm{s}_{\mathrm{i}}-1\right)}{\mathrm{s}_{\mathrm{i}}^{2}} \quad$ with $\quad \mathrm{i}=\mathrm{l}, \mathrm{m}, \mathrm{c}$

Material and labour are complementary factor inputs while capital and labour as well as material and capital are substitutes. However, the substitutability between material and capital is very low. A problem appears to be the value of -165 for $\varepsilon_{l l}$ which might be due to the specification problems for $\beta_{\mathrm{lc}}, \beta_{\mathrm{ym}}$ and $\beta_{\mathrm{yl}}$. Furthermore, we can observe rather price inelastic factor demands with $\left|\varepsilon_{\mathrm{ii}}\right|$ ranging from 0.17 to 0.48 .

Returns to scale were calculated at the sample mean according to 


$$
\begin{aligned}
\mathrm{RTS} & =\frac{1}{\varepsilon_{\mathrm{y}}}=\frac{1}{\partial \ln \mathrm{C} / \partial \ln \mathrm{Y}} \\
& =\frac{1}{\beta_{\mathrm{y}}+\beta_{\mathrm{yy}} \cdot \ln \mathrm{Y}+\beta_{\mathrm{yl}} \cdot \ln \mathrm{W}_{\mathrm{l}}+\beta_{\mathrm{ym}} \cdot \ln \mathrm{W}_{\mathrm{m}}+\beta_{\mathrm{yc}} \cdot \ln \mathrm{W}_{\mathrm{c}}}
\end{aligned}
$$

They amount to 0.66 indicating considerable economies of scale in the renewal process of motorways.

Also for model II we can see that almost all parameters of interest have the expected signs and are significant at 5\% critical level or at least at 10\% level (table 3). Exceptions are the interaction term between labour and capital, the second-order term for the traffic volume of passenger cars and some of the material dummies. There is a problem regarding the properties of the cost function due to the fact that one input cost share is not positive. We will therefore not analyse and compare the input cost shares and the elasticities between the two models. The age variable including the second-order and interaction terms as well as the variable indicating past renewal levels were excluded from the original model (5) due to partly wrong signs and missing significance. The failure of specifying a model with age variables might be explained by the fact that the age variable was used as a rather indirect reflection of construction standards and design parameters anticipated in the original road design. Also the categorical variable indicating the level of past renewal expenditures could only serve as a proxy instead of the ideal measurement of the time period between two renewals at each single section. We also excluded the climate variable from the model due to wrong signs of the estimates and missing significance. Obviously, this variable was constructed from a too aggregated set of variables. ${ }^{1}$

Most important for pricing policy is to obtain estimates of marginal costs, in case of infrastructure damage costs in particular for goods vehicles and ideally further differentiated for different weight classes. Model II allows this type of analysis. However, because the study had no access to axle-load data, it is restricted to an average figure for goods vehicles. Figure 1 shows the cost elasticity

\footnotetext{
${ }^{1}$ The level of disaggregation for the climate data was with 260 measurements much lower than those for the dependent variable (1837 motorway sections). The distance between climate stations and motorway section ranged from $3 \mathrm{~km}$ to $82 \mathrm{~km}$ with a mean of $25 \mathrm{~km}$.
} 
$\frac{\partial \ln C}{\partial \ln u_{f}}=\frac{\partial C}{\partial u_{f}} \cdot \frac{u_{f}}{C}=\beta_{f}+\beta_{f f} \ln u_{f}+\beta_{f p} \ln u_{p}$

which expresses the relationship between marginal and average costs. This elasticity was calculated at the mean value of $\mathrm{u}_{\mathrm{p}}$ and ranges from 0.05 to 1.17 with a digressively increasing shape. Multiplying this with an average renewal cost per truck of $€ 1.59^{1}$ yields marginal costs per vehicle-km of trucks between $€ 0.08$ for the minimum AADT of trucks in the sample, $€ 1.39$ for the average AADT of trucks and $€ 1.87$ for the maximum AADT of trucks (figure 2). These cost estimates are for the lower and average utilisation level of roads below those obtained in Lindberg 2002 who derived within an engineering-based approach a cost elasticity between 0.1 and 0.8 and marginal costs between $€ 0.77$ and $€ 1.86$. The higher figures in Lindberg 2002 are explained by the fact that they were obtained from an ideal approach of assuming that renewals which are necessary from the engineering (or physical) point of view are indeed conducted. In contrast to this, the study presented in this paper is based on the actual renewal expenditures. The lower marginal costs in this paper reflect neglected maintenance and renewal in Germany especially in the 90es (see Kunert/Link 1999.

\section{Conclusions}

In this paper two translog models were estimated to analyse the cost behaviour of renewing motorways in Germany, based on observed spending during the 20 year's period from 1980 to 1999. The first model reflects the economic process of motorway renewals in terms of an output variable, measured as sqm renewed road, and factor input quantities and prices for material, labour and capital, while the second model establishes the relationship between the renewal costs and the use of infrastructure and factor inputs and prices. In our analysis we found substantial economies of scale in the renewal work. The conclusion from this is that the road authorities in Germany which tender the renewal tasks in specified lots to construction companies should think about a larger lot size as far as this does not cause to large traffic

\footnotetext{
${ }^{1}$ This value was calculated from the data by assuming that all renewal costs are exclusively allocated to trucks. This assumption seems to be a plausible reflection of the road damage process and is also confirmed by the procedure in most European road accounts.
} 
restrictions during the construction work. Furthermore, the modelling work revealed very low price elasticities of factor demands, complementarity between the input quantities for material and labour and substitutability between capital and labour and, though to a rather low degree, substitutability between material and capital.

With the second model we have estimated a cost elasticity as the ratio between marginal and average cost per truck-km. From this an important information for pricing policy, the marginal renewal cost per vehicle-km of trucks as part of optimal road user charges was derived. The estimates are lower than those obtained for renewal work on Swedish roads within an engineering-based study (see Lindberg 2002), and it can be concluded that the translog approach provides plausible estimates. The marginal cost result in this paper demonstrates clearly the differences between the two approaches. The engineering-based approach assumes that renewal measures which are from the engineering point of view necessary are indeed put into practice, and provides therefore an upper bound of estimates. The econometric approach is based on actual spending which might be below those necessary from an engineering perspective, and provides a lower bound of estimates. Although the findings in this paper confirm this relationship it would be useful to have for one single country results from both approaches since the comparison between Sweden and Germany might be biased to some (unknown) extent.

The value of the analysis presented in this paper can also be seen under practical aspects regarding data availability. The engineering approach requires cross-sectional, annual measurements of road conditions for a time horizon which is long enough to cover complete renewal cycles. This type of data is often hard to obtain. Although the data requirements for the translog approach are considerable too, this approach might be a useful alternative in cases were the measurement data for the engineering approach are not available.

Not unlike many econometric models a proportion of cost behaviour remains at the current stage unexplained. With improvements of the data base, in particular the inclusion of axleload data and further explanatory variables, it is hoped that this problem can be solved. This holds also true for the desire to have marginal cost estimates for different weight classes of goods vehicles. 


\section{Appendix}

\section{Table 1: Description of input data}

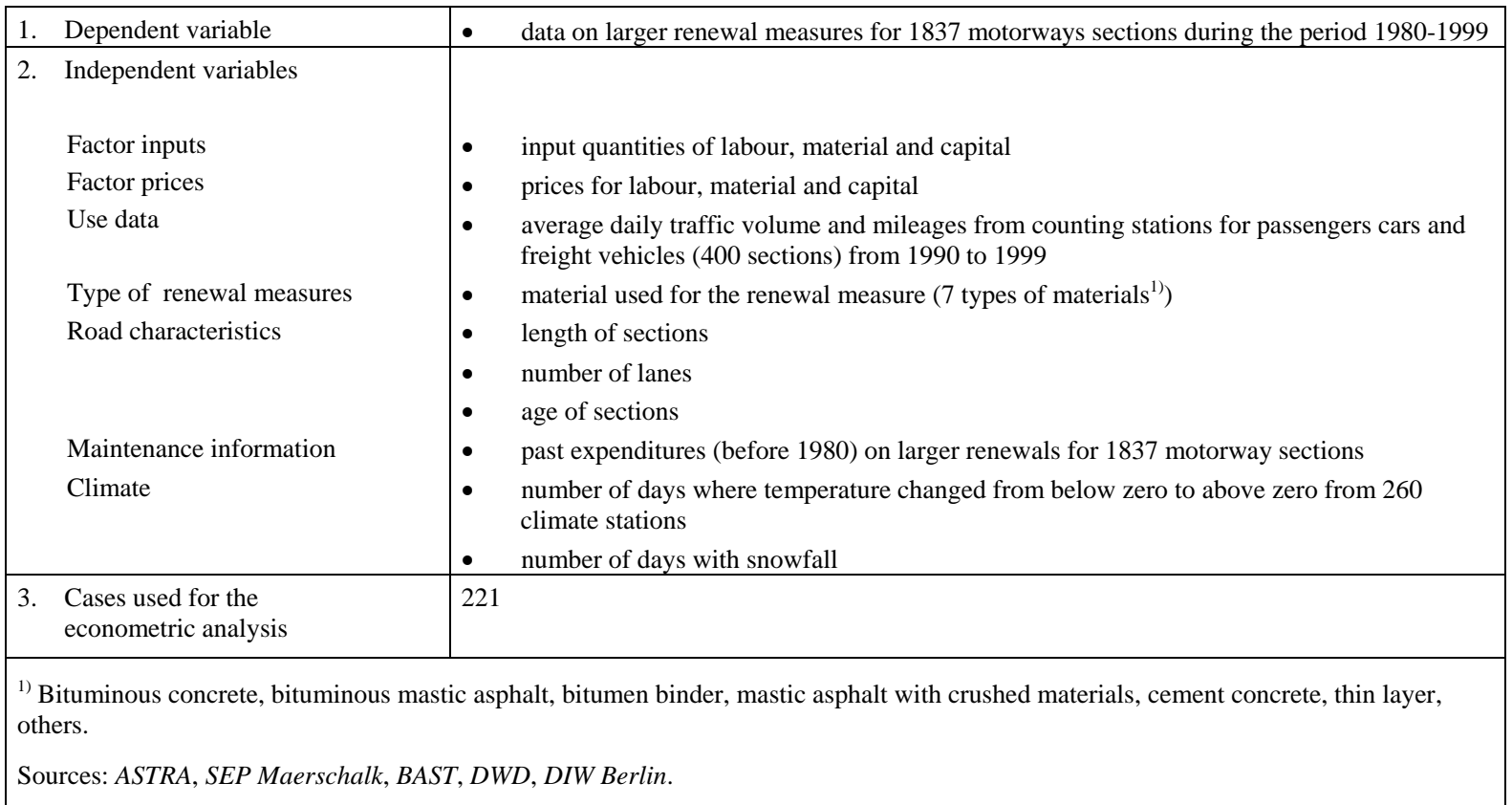

Table 2: Descriptive analysis of German motorway data*

\begin{tabular}{|c|c|c|c|c|c|}
\hline Variable & $\begin{array}{l}\text { Number of } \\
\text { valid cases }\end{array}$ & Mean & Minimum & Maximum & $\begin{array}{l}\text { Standard } \\
\text { deviation }\end{array}$ \\
\hline \multirow[t]{2}{*}{ Renewal costs per section ${ }^{11}$ (DM million) } & 221 & 1.95 & 0.01 & 11.17 & 2.25 \\
\hline & $(1830)$ & (1.73) & (0) & (29.34) & (2.79) \\
\hline \multirow[t]{2}{*}{ Section length (km) } & 221 & 6.60 & 0.44 & 18.78 & 3.61 \\
\hline & $(4138)$ & $(4.48)$ & $(0.031)$ & (23.03) & (3.44) \\
\hline \multirow[t]{2}{*}{ Number of lanes } & 221 & 2.39 & 2 & 3 & 0.489 \\
\hline & $(4134)$ & $(2.2)$ & (1) & (4) & $(0.43)$ \\
\hline \multirow[t]{2}{*}{ Renewal costs before 1980 (DM million) } & 221 & 0.97 & 0 & 14.63 & 2.22 \\
\hline & (1243) & (0.99) & (0) & $(18.76)$ & $(2.37)$ \\
\hline \multirow[t]{2}{*}{ Climate variable $^{2)}$} & 221 & 429 & 152 & 688 & 106.96 \\
\hline & (4138) & (429) & (152) & (825) & $(101.9)$ \\
\hline \multirow[t]{2}{*}{$\mathrm{AADT}^{3)}$ passenger cars 1999} & 221 & 26632.2 & 1448 & 60642 & 12375.6 \\
\hline & (694) & (26395.9) & (1448) & (66488) & (130015.7) \\
\hline \multirow[t]{2}{*}{ AADT $^{3)}$ trucks 1999} & 221 & 5001.6 & 384 & 11001 & 2354.7 \\
\hline & (693) & (4521.7) & (339) & (13378) & (2391) \\
\hline
\end{tabular}


Table 3: Regression results of the translog model for German motorway renewal costs

\begin{tabular}{|c|c|c|c|c|c|c|c|c|}
\hline \multicolumn{5}{|c|}{ Model I } & \multicolumn{4}{|c|}{ Model II } \\
\hline & Coefficients & $\begin{array}{l}\text { Standard } \\
\text { deviation }\end{array}$ & t-value & $\begin{array}{c}\text { Significance } \\
\text { level }\end{array}$ & Coefficients & $\begin{array}{l}\text { Standard } \\
\text { deviation }\end{array}$ & t-value & $\begin{array}{c}\text { Significance } \\
\text { level }\end{array}$ \\
\hline constant & 2.057 & 0.0253 & 81.174 & 0.000 & -1.996 & 0.0547 & -3.652 & 0.000 \\
\hline$\alpha_{1}$ & -0.683 & 0.0233 & -29.243 & 0.000 & -1.682 & 0.0921 & -18.265 & 0.000 \\
\hline$\alpha_{2}$ & -0.959 & 0.0486 & -19.750 & 0.000 & -1.985 & 0.1872 & -10.604 & 0.000 \\
\hline$\alpha_{3}$ & -0.226 & 0.0149 & -15.224 & 0.000 & -0.638 & 0.0634 & -10.076 & 0.000 \\
\hline$\alpha_{4}$ & -0.504 & 0.0132 & -38.126 & 0.000 & -1.391 & 0.0517 & -26.897 & 0.000 \\
\hline$\alpha_{5}$ & -1.224 & 0.0287 & -42.629 & 0.000 & -2.560 & 0.1006 & -25.430 & 0.000 \\
\hline$\alpha_{6}$ & -0.350 & 0.0189 & -18.550 & 0.000 & -0.7172 & 0.0745 & -9.631 & 0.000 \\
\hline$\alpha_{7}$ & -0.078 & 0.0083 & 0.935 & 0.350 & 0.0589 & 0.0340 & 1.732 & 0.083 \\
\hline$\alpha_{8}$ & -0.179 & 0.0100 & -1.794 & 0.073 & -0.0361 & 0.0408 & -0.886 & 0.376 \\
\hline$\delta_{1}$ & - & - & - & - & -0.0375 & 0.0551 & -0.681 & 0.496 \\
\hline$\delta_{2}$ & - & - & - & - & -0.1139 & 0.0535 & -2.130 & 0.033 \\
\hline$\delta_{3}$ & - & - & - & - & -0.0528 & 0.0459 & -1.151 & 0.249 \\
\hline$\delta_{4}$ & - & - & - & - & -0.0716 & 0.0469 & -1.523 & 0.128 \\
\hline$\delta_{5}$ & - & - & - & - & -0.2553 & 0.1342 & -1.902 & 0.057 \\
\hline$\delta_{6}$ & - & - & - & - & -0.0179 & 0.0551 & -0.326 & 0.745 \\
\hline$\delta_{7}$ & - & - & - & - & .) & 1) &.${ }^{1)}$ & .) \\
\hline$\beta_{1}$ & 0.0028 & 0.0005- & 6.008 & 0.000 & 0.0026 & 0.0002 & 17.266 & 0.000 \\
\hline$\beta_{\mathrm{c}}$ & 0.1530 & 0.0114 & 13.429 & 0.000 & 0.6428 & 0.0112 & 57.392 & 0.000 \\
\hline$\beta_{\mathrm{m}}$ & 0.8442 & 0.0113 & 74.476 & 0.000 & 0.3546 & 0.0112 & 31.732 & 0.000 \\
\hline$\beta_{\mathrm{y}}$ & 0.8754 & 0.0253 & 48.383 & 0.000 & - & - & - & - \\
\hline$\beta_{\mathrm{f}}$ & - & - & - & - & 0.1457 & 0.0553 & 2.637 & 0.008 \\
\hline$\beta_{\mathrm{fp}}$ & - & - & - & - & -0.1219 & 0.0517 & -2.357 & 0.018 \\
\hline$\beta_{\mathrm{II}}$ & 0.0015 & 0.0001 & 10.349 & 0.000 & 0.0015 & 0.0001 & 11.358 & 0.000 \\
\hline$\beta_{\mathrm{cc}}$ & 0.1088 & 0.0059 & 18.186 & 0.000 & 0.1228 & 0.0053 & 23.238 & 0.000 \\
\hline$\beta_{\mathrm{mm}}$ & 0.1105 & 0.0059 & 18.660 & 0.000 & 0.1244 & 0.0053 & 23.638 & 0.000 \\
\hline$\beta_{\mathrm{yy}}$ & 0.1193 & 0.0066 & 17.935 & 0.000 & - & - & - & - \\
\hline$\beta_{\mathrm{ff}}$ & - & - & - & - & 0.3752 & 0.1002 & 3.745 & 0.000 \\
\hline$\beta_{\mathrm{pp}}$ & - & - & - & - & 0.1434 & 0.1289 & 1.112 & 0.266 \\
\hline$\beta_{\mathrm{lc}}$ & 0.0001 & 0.0002 & 0.803 & 0.422 & 0.00001 & 0.00009 & 0.193 & 0.847 \\
\hline$\beta_{\mathrm{lm}}$ & -0.0016 & 0.0002 & -9.652 & 0.000 & -0.0015 & 0.0002 & -9.586 & 0.000 \\
\hline$\beta_{\mathrm{mc}}$ & -0.1088 & 0.0059 & -18.300 & 0.000 & -0.1229 & 0.0053 & -23.301 & 0.000 \\
\hline$\beta_{\mathrm{yl}}$ & -0.00007 & 0.0002 & -0.423 & 0.672 & - & - & - & - \\
\hline$\beta_{\mathrm{yc}}$ & -0.1099 & 0.0051 & -21.453 & 0.000 & - & - & - & - \\
\hline$\beta_{\mathrm{ym}}$ & 0.1099 & 0.0051 & 21.577 & 0.000 & - & - & - & - \\
\hline$\beta_{\mathrm{pf}}$ & - & - & - & - & -0.2644 & 0.1070 & -2.471 & 0.014 \\
\hline
\end{tabular}


Table 4: Substitution elasticities and own price elasticities of factor demand

\begin{tabular}{|c|c|c|c|}
\hline \multicolumn{4}{|c|}{ Substitution elasticities ${ }^{1)}$} \\
\hline & Labour $\left(\mathrm{W}_{\mathrm{L}}\right)$ & Capital $\left(\mathrm{W}_{\mathrm{c}}\right)$ & Material $\left(\mathrm{W}_{\mathrm{m}}\right)$ \\
\hline Labour $\left(W_{L}\right)$ & -165.019 & & \\
\hline Capital $\left(\mathrm{W}_{\mathrm{c}}\right)$ & 1.063 & -0.250 & \\
\hline Material $\left(\mathrm{W}_{\mathrm{m}}\right)$ & -0.717 & 0.503 & -1.026 \\
\hline \multicolumn{4}{|c|}{ Own-price elasticities of factor demand ${ }^{1)}$} \\
\hline & -0.479 & -0.167 & -0.335 \\
\hline
\end{tabular}

Figure 1: Cost elasticity (ratio between marginal and average costs) of trucks at German motorways



Source: Own calculations. 
Figure 2: Marginal costs per truck-km at German motorways

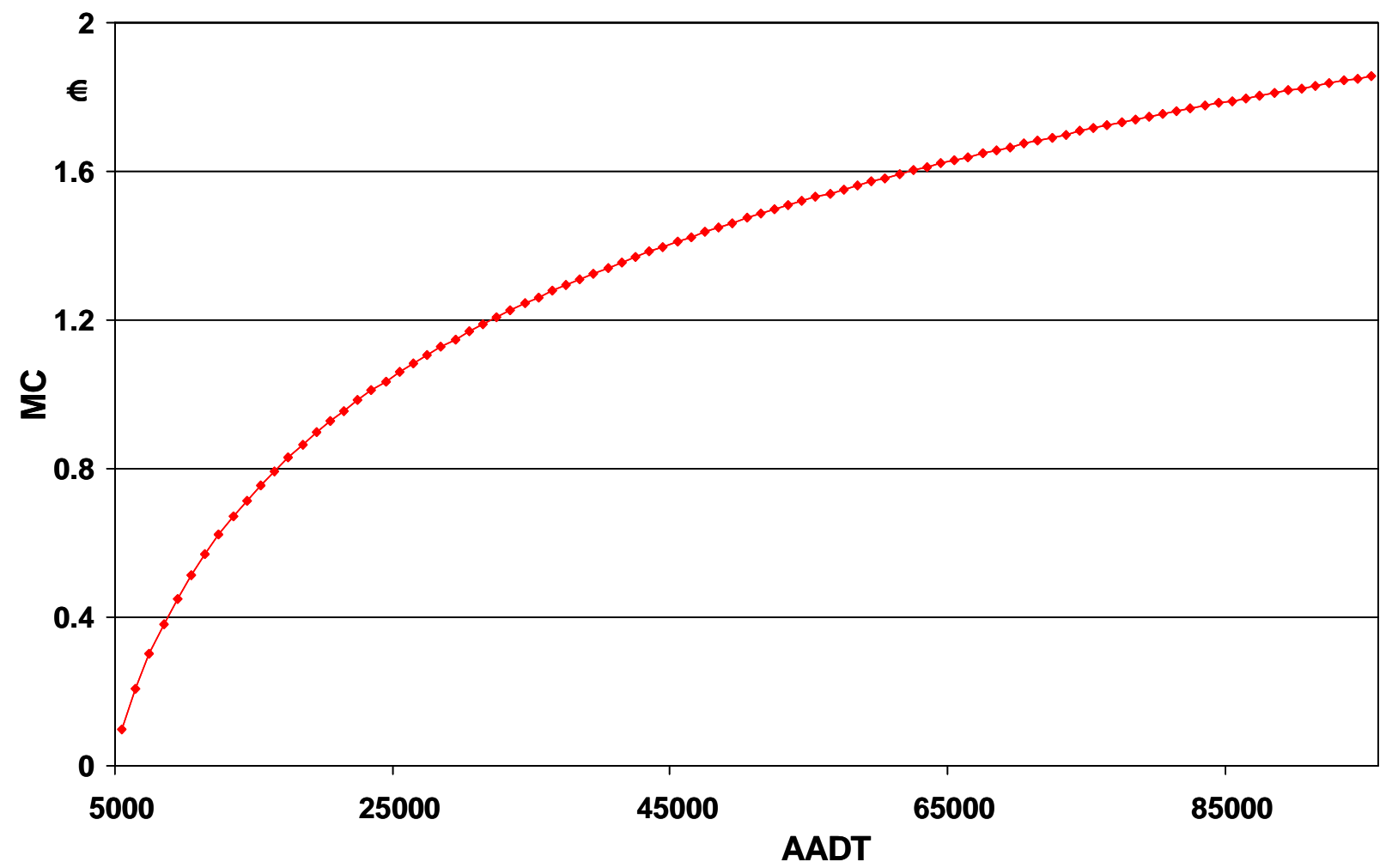

Source: Own calculations. 


\section{References}

ASTRA, 2001. Regionalisierte Langfristprognose des Erhaltungsbedarfs der Bundesautobahnen bis 2015 unter besonderer Berücksichtigung der Controllingfunktion des Bundes bei deren Umsetzung. Projekt-Nr. 28.005/1999 im Auftrage des Bundesministeriums für Verkehr, Bau- und Wohnungswesen. Ingenieurbüro ASTRA GmbH, Berlin.

Berndt, E.R., L.R. Christensen, 1972. The translog function and the substitution of equipment, structures and labour in U.S. manufacturing, 1929-1968. Journal of Econometrics, 1, 81-114.

Barten, A., 1969. A maximum likelihood estimation of a complete system of demand equations. European Economic Review, Fall, 1, 7-73.

Berndt, E.R., M.S. Khaled, 1979. Parametric Productivity Measurement and Choice among Flexible Functional Forms. Journal of Political Economy, 87, 1220-1245.

Cantos, $P$., 2000. A subadditivity test for the cost function of the principal European railways. Transport Reviews, Vo. 20, No. 3, 275-290.

Caves, D.W., L.R. Christensen, M.W. Tretheway, R.J. Windle, 1985. Network effects and the measurement of returns to scale and density for U. S. railroads. In: A.F. Daughety (Ed.), Analytical Studies in Transport Economics, Cambridge University Press.

Christensen, L., D. Jorgenson, L. Lau, 1975. Transcendental Logarithmic Utility Functions. American Economic Review, 65, 367-383.

Davidson, R., J. MacKinnon, 1985. Testing Linear and Loglinear Regressions Against BoxCox Alternatives. Canadian Journal of Economics, 18, 499-517.

Daughety, A.F., F.D. Nelson, W.R. Vigdor, 1985. An econometric analysis of the cost and production structure of the trucking industry. In: A.F. Daughety (Ed.), Analytical Studies in Transport Economics, Cambridge University Press.

De Borger, B., 1992. Estimating a multiple output generalised Box-Cox cost function. European Economic Review, 36, 1379-1398.

Gaudry, M., E. Quinet, 2003. Rail track wear-and-tear costs by traffic class in France. Université de Montreal, Publication AJD-66.

Greene, W.H., 2000. Econometric Analysis. Prentice Hall.

Hermansson, A., 2001. Frost Modelling and Pavement Temperatures. Summer Pavement Temperatures and Frost Modelling. Ph. D. Thesis, Lulea University and Swedish National Road and Transport Research Institute (VTI Särtryck 344), Linköping.

Highway Research Board, 1961. The AASHO-Road-Test - History and Description of Project. Special Report 61 A, Washington D.C. 
Johansson, P., J.E. Nilsson, 2002. An Economic Analysis of Track Maintenance Costs. UNITE (UNIfication of accounts and marginal costs for Transport Efficiency) Deliverable 10, Annex A3. Funded by EU 5th Framework RTD Programme. ITS, University of Leeds, Leeds. http://www.its.leeds.ac.uk/projects/unite/.

Kunert, U., H. Link, 1999. Prognose des Ersatzinvestitionsbedarfs für die Bundesverkehrswege bis zum Jahr 2020. Beiträge zur Strukturforschung des DIW 187, Berlin.

Lindberg, G., 2002. Marginal Costs of road maintenance for heavy goods vehicles on Swedish roads. UNITE (UNIfication of accounts and marginal costs for Transport Efficiency) Deliverable 10, Annex A2. Funded by EU 5th Framework RTD Programme. ITS, University of Leeds, Leeds. http://www.its.leeds.ac.uk/projects/ unite/.

Link, H., J. Dodgson, M. Maibach, Herry, 1999. The Costs of Road Infrastructure and Congestion in Europe. Physica/Springer, Heidelberg.

Newbery, D.M., 1988a. Road Users Charges in Britain. The Economic Journal, 98, 161-176.

Newbery, D.M., 1988b. Road Damage Externalities and Road User Charges. Econometrica, 56, 295-316.

Newbery, D.M., 1989. Cost Recovery from Optimally Designed Roads. Economica, 56, 165185.

Oum, T.H., W.G. Waters II, 1998. Recent Developments in Cost Function Research in Transportation. In: G. De Rus, C. Nash, (Eds.), Recent Developments in Transport Economics. Ashgate Publishing, Aldershot, 33-73.

Ozbay, K., B. Bartin, J. Berechman, 2001. Estimation and evaluation of full marginal costs of highway transportation in New Yersey. Journal of Transportation Statistics, Vol. 4, No. 1.

Rübensam, J., F. Schulze, 1995. Auswertung von Langzeitbeobachtungensdaten zur Beantwortung von Fragestellungen des Managements der Straßenerhaltung. Forschung Straßenbau und Straßenverkehrstechnik 712, Bonn.

Shephard, R.W., 1970. The Theory of Cost and Production. Princeton: Princeton University Press.

Small, K.A., C. Winston, C.A. Evans, 1989. Road work: a new highway pricing and investment policy. The Bookings Institution, Washington.

Talvitie, A.P., C. Sikow, 1992. Analysis of Productivity in Highway Construction using Alternative Average Cost Definitions. Transportation Research 26B, No. 6, 461-478. 